\title{
Rickettsial infection in ticks infesting wild birds from two eco-regions of Argentina
}

\author{
Infecção por riquétsias em carrapatos de aves silvestres em duas ecorregióes da Argentina \\ Fernando Sebastián Flores ${ }^{1}$; Francisco Borges Costa $^{2}$; Santiago Nava ${ }^{3}$; Luiz Adrián Diaz ${ }^{1,4}$; Marcelo Bahia Labruna ${ }^{2 *}$ \\ ${ }^{1}$ Instituto de Virología “Dr. J. M. Vanella”, Facultad Ciencias Médicas, Universidad Nacional de Córdoba - UNC, Ciudad \\ Universitaria, Córdoba, Argentina \\ ${ }^{2}$ Departamento de Medicina Veterinária Preventiva e Saúde Animal, Faculdade de Medicina Veterinária e Zootecnia, Universidade de \\ Sáo Paulo - USP, São Paulo, SP, Brasil \\ ${ }^{3}$ Estación Experimental Agropecuaria Rafaela - EEA, Instituto Nacional de Tecnología Agropecuaria - INTA, Consejo Nacional de \\ Investigaciones Científicas y Técnicas - CONICET, Rafaela, Santa Fe, Argentina \\ ${ }^{4}$ Instituto de Investigaciones Biológicas y Tecnológicas, Consejo Nacional de Investigaciones Científicas y Técnicas - CONICET, \\ Facultad de Ciencias Exactas, Físicas y Naturales - FCEFyN, Universidad Nacional de Córdoba - UNC, Córdoba, Argentina
}

Received February 25, 2016

Accepted April 11, 2016

\begin{abstract}
Several tick-borne Rickettsia species are recognized human pathogens in Argentina. Here we evaluated rickettsial infection in ticks collected on passerine birds during 2011-2012 in two eco-regions of Argentina. The ticks were processed by molecular analysis through polymerase chain reaction (PCR) detection and DNA sequencing of fragments of two rickettsial genes, $g l t A$ and $\operatorname{smp} A$. A total of 594 tick specimens (532 larvae and 62 nymphs), representing at least 4 species (Amblyomma tigrinum, Ixodes pararicinus, Haemaphysalis juxtakochi, Haemaphysalis leporispalustris), were evaluated. At least one A. tigrinum larva, collected on Coryphospingus cucullatus in Chaco Seco, was infected with Rickettsia parkeri, whereas at least 12 larvae and 1 nymph of I. pararicinus, collected from Troglodytes aedon, Turdus amaurochalinus, Turdus rufiventris, C. cucullatus and Zonotrichia capensis, were infected with an undescribed Rickettsia agent, genetically related to several rickettsial endosymbionts of ticks of the Ixodes ricinus complex. $R$. parkeri is a recognized human pathogen in several American countries including Argentina, where a recent study incriminated A. tigrinum as the potential vector of $R$. parkeri to humans. Birds could play an important role in dispersing $R$. parkeri-infected $A$. tigrinum ticks. Additionally, we report for the first time a rickettsial agent infecting $I$. pararicinus ticks.
\end{abstract}

Keywords: Rickettsia parkeri, endosymbiont, Amblyomma tigrinum, Ixodes pararicinus, passeriformes.

\section{Resumo}

Algumas espécies de Rickettsia transmitidas por carrapatos são reconhecidos como patógenos humanos na Argentina. Este presente trabalho avaliou a infecção por Rickettsia em carrapatos coletados em aves passeriformes, durante 2011-2012, em duas ecorregióes da Argentina. Os carrapatos foram processados pela reaçáo em cadeia da polimerase (PCR) e sequenciamento de DNA de dois genes de Rickettsia: gltA e ompA. Ao todo, 594 amostras de carrapatos (532 larvas e 62 ninfas), representando pelo menos 4 espécies (Amblyomma tigrinum, Ixodes pararicinus, Haemaphysalis juxtakochi, Haemaphysalis leporispalustris), foram avaliadas. Pelo menos uma larva de A. tigrinum, coletada de Coryphospingus cucullatus no Chaco Seco, estava infectada com Rickettsia parkeri, enquanto pelo menos 12 larvas e 1 ninfa de I. pararicinus, coletadas de Troglodytes aedon, Turdus amaurochalinus, Turdus rufiventris, C. cucullatus e Zonotrichia capensis estavam infectadas com Rickettsia sp., geneticamente relacionada a vários endossimbiontes riquetsiais de carrapatos do complexo Ixodes ricinus. $R$. parkeri é reconhecidamente um patógeno humano em alguns países americanos, incluindo a Argentina, onde um estudo recente incriminou $A$. tigrinum como um provável vetor. Aves poderiam desempenhar um papel importante na dispersão de carrapatos $A$. tigrinum infectados por $R$. parkeri. Em adiçáo, relata-se pela primeira vez a infecção por Rickettsia em I. pararicinus.

Palavras-chave: Rickettsia parkeri, endo-simbionte, Amblyomma tigrinum, Ixodes pararicinus, passeriformes. 
Bacteria of the genus Rickettsia are obligate intracellular organisms that infect invertebrate hosts worldwide. Some of them also infect and cause diseases (i.e., rickettsioses) in warm-blooded animals and humans, to whom they are transmitted by hematophagous vectors, mostly ticks (PAROLA et al., 2013). In Argentina, three species of the spotted fever group (SFG) rickettsiae, Rickettsia rickettsii, Rickettsia parkeri and Rickettsia massiliae, are recognized as agents of human diseases (PADDOCK et al., 2008; GARCÍA-GARCÍA et al., 2010; ROMER et al., 2011, 2014). A fourth human pathogen, Rickettsia sp. strain Atlantic rainforest has also been reported in Argentinean ticks (MONJE et al., 2015); however, no human cases of rickettsiosis attributed to this pathogen have been detected in Argentina. Additional rickettsial agents of unknown pathogenicity have been reported in Argentinean ixodid ticks, namely Rickettsia bellii, "Candidatus Rickettsia amblyommii", "Candidatus Rickettsia andeanae", Rickettsia sp. strain El Tunal, and Rickettsia sp. endosymbiont of Amblyomma parvitarsum (LABRUNA et al, 2007; PACHECO et al., 2007; SARACHO BOTTERO et al., 2015; TARRAGONA et al., 2015; OGRZEWALSKA et al., 2016).

Wild birds can be hosts of different stages of some species of ticks, commonly larvae and nymphs, and rarely adults (GUGLIELMONE et al., 2014; FLORES et al., 2014). Furthermore, wild birds are among the most mobile hosts, and therefore they may be regarded as hosts with relevant potential in the dispersion of ticks and tick-borne diseases, including rickettsial organisms (ELFVING et al., 2010; HORNOK et al., 2014; BERTHOVÁ et al., 2016). Among 127 species of Ixodidae established in the Neotropical Zoogeographic Region (GUGLIELMONE et al., 2014; NAVA et al., 2014a, b; KRAWCZAK et al., 2015), 39 are found in Argentina (GUGLIELMONE \& NAVA, 2005, 2006; NAVA et al., 2009, 2014a, b). Most of these species belong to the genus Amblyomma, best represented in Argentina with 25 species. Ten species from three genera have been reported parasitizing wild birds in different Argentinean eco-regions (FLORES et al., 2014); however, bird ticks have never been searched for rickettsial infection in Argentina. Here, we have evaluated rickettsial infection in ticks collected on wild birds in two eco-regions of Argentina.

This study was conducted in two localities of the Chaco Seco eco-region (Chaco Seco1: 30 50'S, 62 $54^{\circ} \mathrm{W}$; and Chaco Seco 2: $30^{\circ} 22^{\prime} \mathrm{S}, 64^{\circ} 21^{\prime} \mathrm{W}$ ) and one in the Yungas ecoregion (Parque

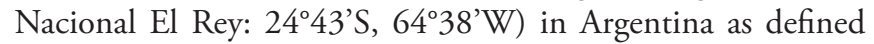
by Burkart et al. (1999). Bird collections were performed using mist nets, which remained active during morning and twilight hours, obtaining convenience samplings in 2011 and 2012, as previously reported (FLORES et al., 2014). Each individual bird was identified using Narosky \& Yzurieta (2010), classified under Clements et al. (2015) criteria and examined for ticks using fine-tipped tweezers. After being processed, the birds were released, and the ticks obtained were stored in $70 \%$ ethanol until specific determination in the laboratory. The detailed procedures for the fieldwork, bird and tick taxonomic identification, and the results of the ticks infesting these birds have been published elsewhere (FLORES et al., 2014).

Ticks of the same developmental stage, collected from the same individual host, were processed in pools of 1 to 39 larvae (median: 4) or 1 to 4 nymphs (median: 1). Ticks from each pool were crushed with a sterile pestle in a microtube, and then processed for DNA extraction by using the AxyPrep Body Fluid Viral DNA/RNA Miniprep Kit (Axygen Biosciences, USA) following the manufacturer's procedures. DNA samples were processed by PCR using primers CS-78 and CS-323 targeting a 398-bp fragment of the citrate synthase gene $(\mathrm{glt} A)$, which occurs in all Rickettsia species (LABRUNA et al., 2004). Samples positive by this first PCR assay were tested by a second PCR assay with primers $\operatorname{Rr} 190.70 \mathrm{p}$ and $\operatorname{Rr} 190.701$, which amplifies $\mathrm{a} \approx 630-\mathrm{bp}$ fragment of the $190-\mathrm{kDa}$ outer membrane protein gene (ompA) of the majority of the SFG Rickettsia species (ROUX et al., 1996). PCR products were DNA-sequenced and subjected to BLAST analyses (BLAST, 2015) to infer the closest similarities available in GenBank.

A total of 594 tick specimens (532 larvae and 62 nymphs), representing at least 4 species, were evaluated in 124 pools for rickettsial infection (Table 1). A complete list of hosts for these ticks has been published elsewhere (FLORES et al., 2014). Two tick species were found to be infected by Rickettsia. One Amblyomma tigrinum pool of 4 larvae was infected with $R$. parkeri, as its gltA and $o m p A$ DNA partial sequences (308 bp and $551 \mathrm{bp}$, respectively) were $100 \%$ identical to $R$. parkeri strain Maculatum 20 (GenBank accession numbers U59732 and U43802, respectively).

Thirteen pools of Ixodes pararicinus (12 out of 32 larval pools; and 1 out of 8 nymphal pools) yielded PCR products for both the $g l t A$ and the ompA genes. DNA sequences were successfully obtained for 5 pools, which generated identical sequences for each rickettsial gene. The gltA partial sequence was $100 \%$ (350/350-bp) identical to Rickettsia sp. strain BelizeIaff1 of Ixodes affinis (KU001172; from Belize), 99.7\% (349/350-bp) identical to Rickettsia sp. strain 12G1 of Rhipicephalus (Boophilus) microplus (KF831359; from Ecuador) and 99.4\% (348/350-bp) identical to Rickettsia monacensis of Ixodes ricinus (LN794217; from Europe) and Rickettsia sp. strain Barva1 of Ixodes minor (KF702332; from Costa Rica). The ompA partial sequences generated from the I. pararicinus ticks were $100 \%$ (587/587-bp) identical to Rickettsia sp. strain Barva2 of Ixodes minor (KF702334; from Costa Rica), 99.8\% (586/587-bp) identical to Rickettsia sp. strain BelizeIaff2 of I. affinis (KU001175; from Belize), and then $98.9 \%$ (572/578-bp) identical to Rickettsia sp. endosymbiont of Ixodes scapularis (EF689735; from the United States).

The GenBank nucleotide sequence accession numbers for the partial sequences generated in this study are KU744411-KU744412 for the glt $A$ and ompA genes of $R$. parkeri from $A$. tigrinum and KU744413-KU744414 for the $g l t A$ and ompA genes of Rickettsia sp. from I. pararicinus.

This study provides molecular evidence of two rickettsial agents infecting ticks that were parasitizing birds in Argentina. $R$. parkeri is a recognized human pathogen in several countries of the Americas (PAROLA et al., 2013), including Argentina, where a recent study incriminated $A$. tigrinum as a probable vector of $R$. parkeri to humans (ROMER et al., 2014). The tick $A$. tigrinum is known to occur in a variety of eco-regions among almost all South American countries (ESTRADA-PEÑA et al., 2005). Recent findings of $R$. parkeri infecting $A$. tigrinum adult ticks in Bolivia (TOMASSONE et al., 2010), Uruguay (LADO et al., 2014), and Argentina (ROMER et al., 2014) suggest that this pathogen could 
Table 1. Ticks collected from birds and tested by PCR for rickettsial infection.

\begin{tabular}{|c|c|c|c|c|c|c|c|}
\hline Tick species & Locality & Tick stage & No. ticks & No. pools & $\begin{array}{c}\text { No. pools infected } \\
\text { by rickettsia }\end{array}$ & $\operatorname{MIR}^{\mathrm{a}}$ & $\begin{array}{c}\text { Bird host species of the } \\
\text { infected ticks }\end{array}$ \\
\hline \multirow[t]{4}{*}{ Amblyomma tigrinum } & Chaco Seco 1 & Larva & 93 & 16 & 0 & 0 & \\
\hline & & Nymph & 18 & 12 & 0 & 0 & \\
\hline & Chaco Seco 2 & Larva & 89 & 14 & 1 & 1.1 & Coryphospingus cucullatus \\
\hline & & Nymph & 20 & 14 & 0 & 0 & \\
\hline \multirow[t]{2}{*}{ Ixodes pararicinus } & Yungas & Larva & 229 & 32 & $12^{c}$ & 5.2 & $\begin{array}{l}\text { Troglodytes aedon, } \\
\text { Turdus amaurochalinus, } \\
\text { Turdus rufiventris, } \\
\text { Coryphospingus cucullatus, } \\
\text { Zonotrichia capensis }\end{array}$ \\
\hline & & Nymph & 11 & 8 & 1 & 9 & Turdus rufiventris \\
\hline \multirow[t]{2}{*}{ Haemaphysalis juxtakochi } & Yungas & Larva & 78 & 10 & 0 & 0 & \\
\hline & & Nymph & 12 & 5 & 0 & 0 & \\
\hline \multirow[t]{2}{*}{ Haemaphysalis leporispalustris } & Yungas & Larva & 23 & 4 & 0 & 0 & \\
\hline & & Nymph & 1 & 1 & 0 & 0 & \\
\hline Haemaphysalis sp. & Yungas & Larva & 10 & 4 & 0 & 0 & \\
\hline Amblyomma sp. & Yungas & Larva & 10 & 4 & 0 & 0 & \\
\hline
\end{tabular}

have a wide distribution within the South American population of this tick species. Thus, it is likely that wild birds could play an important role in dispersing $R$. parkeri-infected $A$. tigrinum ticks, which could expand the area of human exposure to these ticks, consequently increasing the risk of human rickettsiosis. On the other hand, because all tick-infested birds of this study are considered to be non-migratory species (NAROSKY \& YZURIETA, 2010), their specific role in dispersing infected ticks over long distances should be limited.

Additionally, we report for the first time a rickettsial agent infecting I. pararicinus ticks. Partial molecular characterization of this agent indicates that it is most closely related to SFG rickettsial agents associated with I. affinis (LOPES et al., 2016), I. ricinus (MAIOLI et al., 2012), I. minor (OGRZEWALSKA et al., 2015), and I. scapularis (PAROLA et al., 2013). These four Ixodes species, as well as $I$. pararicinus, belong to the $I$. ricinus species complex, based primarily on morphological and genetic relatedness (KEIRANS et al., 1985; BARBIERI et al., 2013). Interestingly, recent studies have indicated that tick members of the $I$. ricinus species complex are usually infected by species-specific closely related rickettsial organisms, usually considered endosymbionts (KURTTI et al., 2015). Moreover, the I. ricinus associated $R$. monacensis is considered by some authors as a human pathogen (PAROLA et al., 2013). Further studies on isolation and deeper molecular characterization are needed to elucidate the taxonomic status of the rickettsial endosymbiont of $I$. pararicinus.

\section{Acknowledgements}

This work received financial support from Fundação de Amparo a Pesquisa do Estado de São Paulo (FAPESP/CONICET Project no. 2013/50605-6) and Consejo Nacional de Investigaciones Científicas y Técnicas (CONICET/FAPESP Project no. 5112/13).

\section{References}

Barbieri AM, Venzal JM, Marcili A, Almeida AP, González EM, Labruna MB. Borrelia burgdorferi sensu lato infecting ticks of the Ixodes ricinus complex in Uruguay: first report for the Southern Hemisphere. Vector Borne Zoonotic Dis 2013; 13(3): 147-153. http://dx.doi.org/10.1089/ vbz.2012.1102. PMid:23402334.

Basic Local Alignment Search Tool - BLAST [online]. Bethesda: National Center for Biotechnology Information; 2015 [cited 2016 Feb 25]. Available from: www.ncbi.nlm.nih.gov/blast

Berthová L, Slobodník V, Slobodník R, Olekšák M, Sekeyová Z, Svitálková $Z$, et al. The natural infection of birds and ticks feeding on birds with Rickettsia spp. and Coxiella burnetii in Slovakia. Exp Appl Acarol 2016; 68(3): 299-314. http://dx.doi.org/10.1007/s10493-0159975-3. PMid:26477038.

Burkart RN, Bárbaro N, Sánchez R, Gómez D. Eco-regiones de la Argentina [online] Buenos Aires: Programa de Desarrollo Institucional Ambiental; 1999 [cited 2016 Feb 25]. Available from: http://www.sib.gov.ar/archivos/ Eco-Regiones_de_la_Argentina.pdf 
Clements JF, Schulenberg TS, Iliff MJ, Sullivan BL, Wood CL, Roberson D, et al. The ebird/Clements checklist of birds of the world: $v 2015$ [online]. Ithaca: Cornell Lab of Ornithology; 2015 [cited 2016 Feb 25]. Available from: http://www.birds.cornell.edu/clementschecklist/download/

Elfving K, Olsen B, Bergström S, Waldenström J, Lundkvist A, Sjöstedt A, et al. Dissemination of spotted fever Rickettsia agents in Europe by migrating birds. PLoS One 2010; 5(1): e8572. http://dx.doi.org/10.1371/ journal.pone.0008572. PMid:20052286.

Estrada-Peña A, Venzal JM, Mangold AJ, Cafrune MM, Guglielmone AA. The Amblyomma maculatum Koch, 1844 (Acari: Ixodidae: Amblyomminae) tick group: diagnostic characters, description of the larva of $A$. parvitarsum Neumann, 1901, 16S rDNA sequences, distribution and hosts. Syst Parasitol 2005; 60(2): 99-112. http://dx.doi.org/10.1007/s11230-0041382-9. PMid: 15841347.

Flores FS, Nava S, Batallán G, Tauro LB, Contigiani MS, Diaz LA, et al. Ticks (Acari: Ixodidae) on wild birds in north-central Argentina. Ticks Tick Borne Dis 2014; 5(6): 715-721. http://dx.doi.org/10.1016/j. ttbdis.2014.05.004. PMid:25108788.

García-García JC, Portillo A, Núñez MJ, Santibáñez S, Castro B, Oteo JA. A patient from Argentina infected with Rickettsia massiliae. Am J Trop Med Hyg 2010; 82(4): 691-692. http://dx.doi.org/10.4269/ ajtmh.2010.09-0662. PMid:20348520.

Guglielmone AA, Nava S. Las garrapatas argentinas del género Amblyomma (Acari: Ixodidae): distribución y hospedadores. Rev Inv Agropec 2006; 35(3): 133-153.

Guglielmone AA, Nava S. Las garrapatas de la familia Argasidae y de los géneros Dermacentor, Haemaphysalis, Ixodes y Rhipicephalus (Ixodidae) de la Argentina: distribución y hospedadores. Rev Inv Agropec 2005; 34(2): 123-141.

Guglielmone AA, Robbins RG, Apanaskevich DA, Petney TN, EstradaPeña A, Horak IG. The hard ticks of the world (Acari: Ixodida: Ixodidae). Heidelberg: Springer; 2014

Hornok S, Kováts D, Csörgő T, Meli ML, Gönczi E, Hadnagy Z, et al. Birds as potential reservoirs of tick-borne pathogens: first evidence of bacteraemia with Rickettsia helvetica. Parasit Vectors 2014; 7(1): 128. http://dx.doi.org/10.1186/1756-3305-7-128. PMid:24679245.

Keirans JE, Clifford CM, Guglielmone AA, Mangold AJ. Ixodes (Ixodes) pararicinus, n. sp. (Acari: Ixodoidea: Ixodidae), a South American cattle tick long confused with Ixodes ricinus. J Med Entomol 1985; 22(4): 401407. http://dx.doi.org/10.1093/jmedent/22.4.401. PMid:4045937.

Krawczak FS, Martins TF, Oliveira CS, Binder LC, Costa FB, Nunes $\mathrm{PH}$, et al. Amblyomma yucumense n. sp. (Acari: Ixodidae), a parasite of wild mammals in southern Brazil. J Med Entomol 2015; 52(1): 28-37. http://dx.doi.org/10.1093/jme/tju007. PMid:26336277.

Kurtti TJ, Felsheim RF, Burkhardt NY, Oliver JD, Heu CC, Munderloh UG. Rickettsia buchneri sp. nov., a rickettsial endosymbiont of the blacklegged tick Ixodes scapularis. Int J Syst Evol Microbiol 2015; 65(3): 965-970. http://dx.doi.org/10.1099/ijs.0.000047. PMid:25563918.

Labruna MB, Pacheco RC, Nava S, Brandão PE, Richtzenhain LJ, Guglielmone AA. Infection by Rickettsia bellii and Candidatus "Rickettsia amblyommii" in Amblyomma neumanni ticks from Argentina. Microb Ecol 2007; 54(1): 126-133. http://dx.doi.org/10.1007/s00248-006-9180-3. PMid:17264991.

Labruna MB, Whitworth T, Horta MC, Bouyer DH, McBride JW, Pinter A, et al. Rickettsia species infecting Amblyomma cooperi ticks from an area in the state of Sáo Paulo, Brazil, where Brazilian spotted fever is endemic. J Clin Microbiol2004; 42(1): 90-98. http://dx.doi.org/10.1128/ JCM.42.1.90-98.2004. PMid:14715737.

Lado P, Castro O, Labruna MB, Venzal JM. First molecular detection of Rickettsia parkeri in Amblyomma tigrinum and Amblyomma dubitatum ticks from Uruguay. Ticks Tick Borne Dis 2014; 5(6): 660-662. http:// dx.doi.org/10.1016/j.ttbdis.2014.04.021. PMid:25108780.

Lopes MG, May JM Jr, Foster RJ, Harmsen BJ, Sanchez E, Martins TF, et al. Ticks and rickettsiae from wildlife in Belize, Central America. Parasit Vectors 2016; 9(1): 62. http://dx.doi.org/10.1186/s13071-0161348-1. PMid:26831147.

Maioli G, Pistone D, Bonilauri P, Pajoro M, Barbieri I, Patrizia M, et al. Etiological agents of rickettsiosis and anaplasmosis in ticks collected in Emilia-Romagna region (Italy) during 2008 and 2009. Exp Appl Acarol 2012; 57(2): 199-208. http://dx.doi.org/10.1007/s10493-012-9535-z. PMid:22402940.

Monje LD, Nava S, Eberhardt AT, Correa AI, Guglielmone AA, Beldomenico PM. Molecular detection of the human pathogenic Rickettsia sp. strain Atlantic rainforest in Amblyomma dubitatum ticks from Argentina. Vector Borne Zoonotic Dis 2015; 15(2): 167-169. http://dx.doi.org/10.1089/ vbz.2014.1741. PMid:25700048.

Narosky T, Yzurieta D. Aves de Argentina y Uruguay. Buenos Aires: Vázquez Mazzini; 2010.

Nava S, Beati L, Labruna MB, Cáceres AG, Mangold AJ, Guglielmone AA. Reassessment of the taxonomic status of Amblyomma cajennense (Fabricius, 1787) with the description of three new species, Amblyomma tonelliae $\mathrm{n}$. sp., Amblyomma interandinum n. sp. and Amblyomma patinoi n. sp., and reinstatement of Amblyomma mixtum Koch, 1844 and Amblyomma sculptum Berlese, 1888 (Ixodida: Ixodidae). Ticks Tick Borne Dis 2014a; 5(3): 252276. http://dx.doi.org/10.1016/j.ttbdis.2013.11.004. PMid:24556273.

Nava S, Mangold AJ, Mastropaolo M, Venzal JM, Oscherov EB, Guglielmone AA. Amblyomma boeroi n. sp. (Acari: Ixodidae), a parasite of the chacoan peccary Catagonus wagneri (Rusconi) (Artiodactyla: Tayassuidae) in Argentina. Syst Parasitol 2009; 73(3): 161-174. http:// dx.doi.org/10.1007/s11230-009-9191-9. PMid:19472076.

Nava S, Mastropaolo M, Mangold AJ, Martins TF, Venzal JM, Guglielmone AA. Amblyomma hadanii n. sp. (Acari: Ixodidae), a tick from northwestern Argentina previously confused with Amblyomma coelebs Neumann, 1899. Syst Parasitol 2014b; 88(3): 261-272. http://dx.doi.org/10.1007/s11230014-9500-9. PMid:24935128.

Ogrzewalska M, Literák I, Capek M, Sychra O, Calderón VÁ, Rodríguez BC, et al. Bacteria of the genus Rickettsia in ticks (Acari: Ixodidae) collected from birds in Costa Rica. Ticks Tick Borne Dis 2015; 6(4): 478482. http://dx.doi.org/10.1016/j.ttbdis.2015.03.016. PMid:25869035.

Ogrzewalska M, Nieri-Bastos FA, Marcili A, Nava S, González-Acuña D, Muńoz-Leal S, et al. A novel spotted fever group Rickettsia infecting Amblyomma parvitarsum (Acari: Ixodidae) in highlands of Argentina and Chile. Ticks Tick Borne Dis 2016; 7(3): 439-442. http://dx.doi. org/10.1016/j.ttbdis.2016.01.003. PMid:26826974.

Pacheco RC, Moraes-Filho J, Nava S, Brandão PE, Richtzenhain LJ, Labruna MB. Detection of a novel spotted fever group rickettsia in Amblyomma parvum ticks (Acari: Ixodidae) from Argentina. Exp Appl Acarol 2007; 43(1): 63-71. http://dx.doi.org/10.1007/s10493-0079099-5. PMid:17768597.

Paddock CD, Fernández S, Echenique GA, Sumner JW, Reeves WK, Zaki SR, et al. Rocky Mountain spotted fever in Argentina. Am J Trop Med Hyg 2008; 78(4): 687-692. PMid:18385370. 
Parola P, Paddock CD, Socolovschi C, Labruna MB, Mediannikov O, Kernif T, et al. Update on tick-borne rickettsioses around the world: a geographic approach. Clin Microbiol Rev 2013; 26(4): 657-702. http:// dx.doi.org/10.1128/CMR.00032-13. PMid:24092850.

Romer Y, Nava S, Govedic F, Cicuttin G, Denison AM, Singleton J, et al. Rickettsia parkeri rickettsiosis in different ecological regions of Argentina and its association with Amblyomma tigrinum as a potential vector. Am J Trop Med Hyg 2014; 91(6): 1156-1160. http://dx.doi.org/10.4269/ ajtmh.14-0334. PMid:25349376.

Romer Y, Seijo AC, Crudo F, Nicholson WL, Varela-Stokes A, Lash RR, et al. Rickettsia parkeri Rickettsiosis, Argentina. Emerg Infect Dis 2011; 17(7): 1169-1173. http://dx.doi.org/10.3201/eid1707.101857. PMid:21762568.

Roux V, Fournier PE, Raoult D. Differentiation of spotted fever group rickettsiae by sequencing and analysis of restriction fragment length polymorphism of PCR-amplified DNA of the gene encoding the protein rOmpA. J Clin Microbiol 1996; 34(9): 2058-2065. PMid:8862558.

Saracho Bottero MN, Tarragona EL, Nava S. Spotted fever group rickettsiae in Amblyomma ticks likely to infest humans in rural areas from northwestern Argentina. Medicina (B Aires) 2015; 75(6): 391-395. PMid:26707663.

Tarragona EL, Cicuttin GL, Mangold AJ, Mastropaolo M, Nazarena De Salvo M, Nava S. Rickettsia infection in Amblyomma tonelliae, a tick species from the Amblyomma cajennense complex. Ticks Tick Borne Dis 2015; 6(2): 173-177. http://dx.doi.org/10.1016/j.ttbdis.2014.11.010. PMid:25544308.

Tomassone L, Conte V, Parrilla G, De Meneghi D. Rickettsia infection in dogs and Rickettsia parkeri in Amblyomma tigrinum ticks, Cochabamba department, Bolivia. Vector Borne Zoonotic Dis 2010; 10(10): 953-958. http://dx.doi.org/10.1089/vbz.2009.0126. PMid:20426684. 